Newfoundland and Labrador Studies

\title{
The 1938 Holmes Case and Challenging the Statutory Authority of the Commission of Government
}

\section{Melvin Baker}

Volume 34, Number 2, 2019

URI: https://id.erudit.org/iderudit/1072653ar

DOI: https://doi.org/10.7202/1072653ar

See table of contents

Publisher(s)

Faculty of Arts, Memorial University

ISSN

$1719-1726$ (print)

1715-1430 (digital)

Explore this journal

Cite this article

Baker, M. (2019). The 1938 Holmes Case and Challenging the Statutory

Authority of the Commission of Government. Newfoundland and Labrador

Studies, 34(2), 271-295. https://doi.org/10.7202/1072653ar viewed online.

https://apropos.erudit.org/en/users/policy-on-use/ 


\section{The 1938 Holmes Case and Challenging the Statutory Authority of the Commission of Government}

Melvin Baker

\section{Introduction}

On 16 February 1934 a British-appointed Commission of Government was inaugurated in St. John's. The legislature of the Dominion of Newfoundland agreed to suspend responsible government during the height of the Great Depression when it was unable to meet interest payments on its funded debt because of the sharp decline in resourcebased revenues from fishery, forestry, and mineral exports. The Commission had been adopted on the recommendation of a Royal Commission established by the British government a year earlier at the request of the Newfoundland government. The six-member Commission of Government had three Newfoundland and three British members, all selected by London and presided over by a Britishappointed governor. It had full legislative and executive powers subject to the supervisory control of the British government, the Governor-in-Commission being responsible to the Secretary of State for Dominion Affairs. This undemocratic government continued until 1949 when Newfoundland joined Canada, following a majority referendum vote in July $1948 .{ }^{1}$

Although Newfoundland was without democracy during the Commission era, the disenfranchised citizenry did confront state authority, often through the courts. This article examines one such instance when, in 1938, tensions flared between the unelected Commission and the people and business community it governed. The conflict 
arose when a St. John's fish exporter, A.C. Holmes, sought a writ of mandamus from the Newfoundland Supreme Court ordering the Newfoundland Fisheries Board to grant him an export license. ${ }^{2}$ Both the Board and the Commission saw the writ as threatening their efforts at fishery reform and reorganization, thereby prompting the Commission to act swiftly to enact amending legislation to override the Court's action. Although the business community was concerned over the Commission's running roughshod over Holmes's rights, in the end it accepted the Commission's action for the overall good of the economy. The Holmes case, a little known event in the history of the Commission, ${ }^{3}$ shows how an unelected government went too far in undermining a judicial ruling, how the disenfranchised public and the press reacted to that overreach, and the sensitivity of that government to public criticism.

\section{Establishment of the Newfoundland Fisheries Board}

One of the major goals of the Commission in 1934 was the "rehabilitation" of the Newfoundland economy and society along the lines suggested in the 1933 Royal Commission Report. For Sir John Hope Simpson, the first Commissioner for Natural Resources, ${ }^{4}$ this could be achieved through greater government control over the fishery, especially through the production and export marketing of fishery products. In 1936 the Commission established the Newfoundland Fisheries Board and appointed St. John's lawyer and former Board of Trade president Raymond Gushue as its first chair. ${ }^{5}$ The new Fisheries Board, it was hoped, would overcome the deep-rooted suspicion between fishermen and merchants and end cutthroat competition among merchants in export markets. ${ }^{6}$ Its formation followed nearly three decades of efforts by various Newfoundland governments and the Newfoundland Board of Trade (established in 1909) ${ }^{7}$ to provide better regulation over the production and marketing of salt codfish to foreign markets, especially to the major markets of Portugal, Spain, and Italy. Past failures had been the result of the competitive self-interest and inability 
of exporters, mostly based in St. John's, to agree on how that regulation would work. ${ }^{8}$

Section 7 of the 1936 Newfoundland Fisheries Board Act ${ }^{9}$ gave the Board wide authority to "make rules and regulations" and allowed it to "alter, amend and repeal the same from time to time" respecting the catching, curing, preparation, processing, grading, packing, branding, and marketing of fish for export. The Board regulated "sales and shipments of fish to the several markets," while giving the Governor-in-Commission authority to impose a fine or imprisonment or both for a breach of any rules and regulations, as well as the authority to suspend or cancel an export license. Other sections of the Act gave the Fisheries Board powers to issue export licenses and to refuse licenses for export of any firm. The Board could designate markets where no fish could be sold or consigned until a license for such sale or consignment had been obtained. Specifically, subsection 5 authorized the Board, "subject to the approval of the Governor-in-Commission[,] to make rules and regulations relating to sales or consignments to such designated markets and alter, amend and repeal of the same from time to time," while subsection 6 stated the Board could "grant or refuse in the absolute discretion of the Board licenses for the sale or consignment of fish to a designated market." It had authority to determine what brokers would be used to sell fish in markets and to organize groups or associations of exporters to co-ordinate the sale of fish. Thus, the Board had complete regulatory authority over fish exporters, which enabled it to grant or refuse in its "absolute discretion" licenses for the sale or consignment of fish to a designated market. The Commission established under separate legislation the Salt Codfish Association, appointed by the Governor-in-Commission from among exporters as an advisory body to the Board. ${ }^{10}$

The government effectively created a separate department of fisheries without placing a Commissioner solely in charge. As Gushue observed to Hope Simpson on 21 July 1936, the main function of the Fisheries Board was to "perform the administrative work of the Government in relation to fisheries - in other words, it is the Department 
of Fisheries." ${ }^{11}$ On 24 April 1936 the Board approved Portugal as a designated market and fish exporters subsequently organized into a co-operative marketing organization, the Portugal Exporters Group (PEG). The London-based firm Hawes \& Company was appointed as PEG's broker for the sale of Newfoundland fish. The Board intended to organize similar organizations for markets in Greece, Spain, and Puerto Rico, all three of which were also approved for designation in 1936. ${ }^{12}$ Such organizations would bring an end to a "completely uncoordinated mass of individual endeavours" ${ }^{13}$ with co-operative marketing subsequently put in place for several other markets.

\section{Designating Puerto Rico in 1938}

Civil war in Spain and greater regulatory control over fish markets by the respective governments in Portugal and Italy had greatly reduced the market for Newfoundland salt codfish in the late 1930s, prompting exporters ${ }^{14}$ and the Fisheries Board to look for increasing opportunities in the Caribbean. By 1938 Puerto Rico had become a growing and important outlet. Board member John Cheeseman ${ }^{15}$ and Claude Fraser, ${ }^{16}$ secretary for the Department of Natural Resources, had visited Puerto Rico in December 1937 to assess market conditions and recommended that a central selling organization of exporters be set up for Puerto Rico. Salt codfish from the Canadian Maritimes had dominated that market but Newfoundland exports were a close second. In fact, by 1932 Newfoundland's exports to Puerto Rico surpassed those of Canada, because of a reduction in the Lunenburg banking fleet and because the Newfoundland product caught off Labrador was being sold at much lower prices than the Lunenburg bank codfish, which was of a better cure quality. Several of the large Puerto Rican importers had agents in St. John's, while St. John's exporter A.H. Murray and Company had its own subsidiary company in Puerto Rico from 1937 to compete with importers there. ${ }^{17}$ Fish-buying in Puerto Rico was practically in the hands of local Newfoundland firms, and the primary concern of the Newfoundland agents, Fisheries Board chair Gushue 
informed Natural Resources Commissioner Robert Ewbank in October $1938,{ }^{18}$ was to buy fish "as cheaply as possible." At a general meeting of its members on 24 September the Salt Codfish Association approved the idea of a co-operative marketing group based on a division of sales among its members for Puerto Rico. ${ }^{19}$

The Board was determined to control how Newfoundland exporters would manage their access to the Puerto Rican market. It began negotiations with the Association exporters over how to establish this market division, reminding exporters that all sales to Puerto Rico were conditional on their having an approved export license from the Board in consideration of the forthcoming formation of a co-operative marketing group. As part of the negotiations, the Board reached an understanding with the Association that a minimum price set by the government could be paid to fishermen by exporters for the purchase of Labrador salt codfish. The government set aside $\$ 300,000$ in its 1938-39 budget for financial assistance to the fishery, to be applied to a guarantee for Labrador fish sold in markets approved by the Board. The Association and the Board agreed that parties having made sales at lower prices than those set by the Board must clear them by 29 October and were to be notified of this decision so that the exporters' group could commence its work on 1 November when Puerto Rican importer Emiliano Mendez, the owner of Mendez \& Company, was due in St. John's to discuss sales with Puerto Rico Exporters Ltd, which had been incorporated on 25 October $1938 .{ }^{20}$ The Board wanted a contract for 100,000 quintals at $\$ 8.25$ per barrel effective 1 November, ${ }^{21}$ conditional that no other fish would go to Puerto Rico from Newfoundland at a lower price. ${ }^{22}$

\section{Resistance from Holmes}

Not all exporters welcomed the Fisheries Board's determination to bring regulatory order to the marketing of fish. One was Great War veteran Arthur Chesley Holmes (1896-1952), ${ }^{23}$ who in early January 1938 published a series of letters in the press arguing the merits of 
private industry over government control of business. He described the Board's role as "interference." Holmes argued that in Portugal, where such control existed, regulation had not led to higher prices for Newfoundland fish and claimed that the Board did not understand consumer demands for salt codfish. ${ }^{24}$ Holmes was drawing on his prior experience in that country, when he had lived in Oporto as an importer of Newfoundland fish from the 1920s until the 1936 Board-led formation of PEG. His criticisms foretold the difficulties that he would soon encounter with the new Puerto Rican arrangements.

In 1938 Holmes was the Newfoundland agent for Sobrino de Izquierdo Inc. of San Juan, one of Puerto Rico's major fish importers. ${ }^{25}$ He had contracted on 1 September to purchase 6,000 barrels $(12,000$ quintals) of Labrador codfish at $\$ 7$ per barrel from St. John's-based Monroe Export Co Ltd between 15 September and 15 November 1938. Holmes applied to the Board on 20 October for unrestricted export licenses for shipments up to 15 November. Holmes closed one shipment with a license from the Board but was verbally informed at the time of application that he could not have any unrestricted licenses for shipments after 29 October because of the higher price of $\$ 8.25$ effective at the beginning of November, which the Board had established for fish to be sold by Puerto Rico Exporters Ltd. The Board instructed Holmes that he could make another shipment at $\$ 7 / \mathrm{barrel}$ to Puerto Rico and to ship it before 1 November when the new marketing group would be fully in operation. As he did not expect to ship his fish by this date, Holmes applied once more to the Board for a license to ship later, which the Board refused. However, it wrote Holmes on 22 October that his fish could be included in the 100,000 quintals the Board was arranging as a sale to Puerto Rico. (Presumably, this was problematic for Holmes because that fish was to sell at $\$ 8.25$ but Holmes had contracted to sell at \$7.)

When he was refused a second license, Holmes's solicitor, Edmund J. Phelan, ${ }^{26}$ applied on 29 October to the Supreme Court for a writ of mandamus requiring the Board to issue Holmes a license to sell the 6,000 barrels of codfish to Sobrino. ${ }^{27}$ The Court considered 
the writ two days later, and on 2 November the Supreme Court registrar, William R. Howley, ${ }^{28}$ issued an order for the Fisheries Board to show cause by 4 November why the writ should not be issued. Court Justices Kent and Higgins ${ }^{29}$ heard the facts in the case on Thursday 10 November and issued a peremptory writ. Their judgment ordered the Board to allow Holmes his license to sell 6,000 barrels of codfish up to 15 November 1938. The Court held that section 9, subsection 6 of the 1936 Fisheries Board Act must be read in conjunction with subsection 5 , which gave the Board power, subject to the approval of the Governorin-Commission, to make rules and regulations that had to be published in the Nerufoundland Gazette and come into effect from the date of publication of the rules and regulations. The Court ruled that "no such rules or regulations have been either made or published" concerning the newly designated market in Puerto Rico and "we do not think the Board has, in the absence of such rules, an arbitrary right to refuse the issue of licenses under sub-section 4 but are of opinion that the absolute discretion given it must be exercised within the scope of such rules and regulations." Therefore, the withholding of a license to Holmes was not "justified" and, according to the justices, he was "entitled to have the license issued to him in the terms of his application." 30

The Court's decision presented grave consequences for the government's ongoing efforts to regulate the fishery in general and, in particular, to establish co-operative organizations. The following day Gushue, the Fisheries Board chairman, warned Commissioner Ewbank of the "awkward situation ... created" by the Court's action because of the contract Puerto Rico Exporters Ltd on 8 November had signed with Mendez for a minimum of 100,000 quintals of Labrador fish at $\$ 8.25$ per barrel. Mendez had also agreed to pay 50 cents per barrel as a financial penalty that Puerto Rico Exporters Ltd would hold in the event he failed to take the 100,000 quintals. By getting an additional \$1.25 per barrel for Labrador fish, as compared, for example, with the price for which Holmes had contracted, Gushue believed the Puerto Rican market would be placed on a profitable basis and there would be no need for a government guarantee contribution in this market, while 
avoiding any possibility of American countervailing duties being imposed because of the Newfoundland government's price guarantee, which the Americans would regard as a subsidy. Mendez told Newfoundland exporters that he would not make the contract if a license was granted to Holmes under the mandamus proceedings. Gushue advised the government that the "situation created by this judgment [ought] to be remedied promptly, otherwise the effectiveness of the various forms of marketing control will be impaired," and he urged the government to apply to the Court for a clearer definition. ${ }^{31}$

Ewbank's subsequent memorandum prepared for a Commission meeting later on 12 November emphasized that the position was even more difficult than Gushue had described. He argued that if Holmes were to be allowed to ship his fish to Sabrino, "the great rival of Mendez," that would allow Sabrino to put his fish on the market and keep prices at $\$ 7$ for three months, by which time Mendez's contract would have been "completely torpedoed." Moreover, Ewbank believed this situation would encourage others to similarly defy the Board and would lead to the "complete breakup of the Marketing System and an immense increase in the liability under our guarantee would result. If the order stands Government cannot refrain from taking some action." Ewbank said Attorney General L.E. Emerson ${ }^{32}$ would appear at the Supreme Court "this morning and hopes to reverse their order. If he succeeds all is well." If not, there were "two things that we must guard against." First, that Holmes would export fish to Puerto Rico at the $\$ 7$ price because of his license. Second, the position "must be rectified so that the High Court will not issue another Mandamus." On the first point, Ewbank said the government was naturally "most adverse to undertaking retroactive legislation or to following a course which directly challenges the Mandamus issued by the High Court." Ewbank suggested to Emerson that if "we can rush through legislation which puts an additional hurdle in the way of exporters of fish to Puerto Rico for three months at once, the Fisheries Board can obey the High Court and we can bring Mr. Holmes down at the new hurdle. If this was done quickly there would be no need of retrospective effect." On 
the second point, he acknowledged the difficulty in framing regulations since prices and market conditions varied daily and it was impossible to cover all eventualities. Legal remedy was only necessary if Emerson's motion failed on an appeal of the mandamus. ${ }^{33}$

On Saturday morning 12 November, Emerson filed a motion at a Supreme Court hearing for the judgment to be amended or corrected. But the Court upheld its prior decision. When the Fisheries Board then issued Holmes his license at 4:45 p.m., Holmes already had his fish loaded aboard a steamer at St. John's for Halifax and then for transshipment to Puerto Rico. When Holmes went to Harvey \& Company, the steamer's agent, with the new license, company officials informed him that instructions had been issued by Customs that the SS Magnhild was not to be cleared for leaving the port of St. John's without a special permit necessary under new legislation the Commission had passed earlier that afternoon. ${ }^{34}$ Holmes then held Harvey \& Company legally liable for any damage to the fish and the government and the Fisheries Board liable for all loss, damages, costs, charges, and expenses resulting from the refusal to permit the export of the cargo. ${ }^{35}$

To prevent the loss of the more lucrative Mendez contract, the government that same day had held its special meeting enacting new legislation, "An Act to Prohibit the Export of Codfish save under Permit for Export." It would prevent anybody in Newfoundland from shipping any fish to anywhere in the world without first getting an individual permit from the Fisheries Board. The legislation also addressed the Board's authority in designated markets, giving it the necessary administrative powers and making it clear that the Board had the absolute right to grant or refuse licenses. The Act required a special additional permit for export, which could be granted or refused by the Board without assigning any reason for refusal. ${ }^{36}$ Holmes responded the next day (Sunday) with a press interview that was published the following day. He denied he had received any offer from the government and said that the Court saw the Board's action as an illegal attempt to enforce a higher minimum price per barrel on his principal's fish, which was already contracted for $\$ 7$ per barrel. The Board's offer 
to ship some of the Monroe-contracted fish with the marketing group was made in a letter to him dated 22 October before the new marketing group had begun operation, before Mendez's arrival in St. John's on 31 October, and before the conclusion of the Board-approved Mendez 100,000-quintal contract with Puerto Rico Exporters. Holmes suggested that this offer was disingenuous as the marketing group would not allow his principal to acquire the fish at $\$ 7$ per barrel. ${ }^{37}$ Before the matter had reached the Court, Holmes claimed that he had offered a compromise: "I offered to take the fish out of the country in small lots so as not to disturb the Puerto Rico market; my offer was refused. I offered any reasonable guarantee that whether the fish went forward in small lots or big lots, that selling prices in Puerto Rico would not be less than those compatible with Board prices; my offer was refused." Even after the mandamus was issued, Holmes claimed he tried to compromise "by offering to store the fish in Halifax pending Board instructions, as well as giving a letter of guarantee that not a quintal of the fish would be forwarded to Puerto Rico without the consent of the Board." Holmes asserted that "all through I have shown the utmost goodwill but have met with nothing except [obstinacy] and unreasonableness." Holmes had written Gushue of the Fisheries Board on 26 October offering to discuss with him "ways and means of securing the best possible solution of the many problems confronting exporters in Newfoundland and importers in Puerto Rico." Holmes received no reply, "written or verbal." 38

As far as Gushue was concerned, Holmes had deliberately chosen to ignore the Fisheries Board's policies to regulate the Puerto Rican market. Because of the Board's past dealings with Holmes in the Portuguese market, Gushue later told Ewbank that the Board "as a matter of fact" had been "careful to give Mr. Holmes the fairest possible treatment because of certain contentious decisions which the Board was forced to make against Mr. Holmes... . Quite frankly, I think that Mr. Holmes has to be watched and that is why, as I have said above, for some time I have never had a conversation with him without another person present." ${ }^{39}$ Regardless of Gushue's assessment of Holmes, the 
action of the Commission in passing legislation immediately after the Court had upheld Holmes's rights generated controversy.

\section{Public Response}

The Commission of Government quickly realized it might face strong public criticism for its new legislation. Recognizing that the "action taken by us can be represented as an arbitrary interference by an irresponsible executive government with the rights of an individual as established in the High Court," Ewbank acted promptly, releasing a statement on Monday 14 November that he hoped would "suffice to prevent agitation on these lines." ${ }^{40}$ The government believed it had acted to protect the co-operative group marketing system a majority of exporters to Puerto Rico had wanted established. ${ }^{41}$ Ewbank emphasized the reasonableness of the Fisheries Board in offering Holmes the opportunity, in order to "protect" his interests, to hand his fish over to the Puerto Rico Exporters on the understanding that it would come into the 100,000 quintals already negotiated to be sold at $\$ 8.25$ per two-quintal barrel, but it was an offer Holmes refused. The Commission and the Fisheries Board received the qualified support of the Evening Telegram, one of St. John's two major daily newspapers. Editor Charles Jeffery ${ }^{42}$ acknowledged that nothing but the "best intentions can be attributed to the Fisheries Board" in order to protect the value of fish exports, but he also added that the passing of legislation, following the Court's decision, would "seem to involve a very important principle and might result in the establishment of a dangerous precedent." The Supreme Court had been asked to interpret a ruling by the Board and judgment was given as the law stood. ${ }^{43}$

The other major daily newspaper, the Daily News, which was generally critical of the Commission of Government in the late 1930s, swiftly condemned the new legislation and the British-appointed Commission of Government in general, characterizing the "Holmes case" a "local cause celebre." ${ }^{44}$ Even more critical was journalist, businessman, and Commission critic Albert Perlin. ${ }^{45} \mathrm{He}$ wrote in his 
weekly newspaper, the Observer's Weekly, that the government had chosen "as it had a legal right to do, to make the fullest use of the dictatorial powers with which, by the constitution, it has been entrusted. It would have been more tactful to compromise." Perlin quoted from a letter Hope Simpson published in March 1934 in his newspaper where the former Commissioner had said that "it is clear to us, as it must be clear to everyone that no measures which do not command the consent of the moral sense of the people of Newfoundland can be enforced or be effective." However, Perlin did not believe that this was the case of a government abusing its powers; rather, the Commission "honestly thought it was doing the best possible in the national interest." But this was "beside the point," he wrote, because there should be "safeguards in the form of regulation of legislative processes which would permit the public to know what is planned and to offer an expression of opinion upon the Government's policy as set forth in legislation. The present makes this need all the more apparent and I trust that steps will soon be taken to provide the necessary safeguards for the protection of our democratic principles as well as for the protection of the Government's own interests." ${ }^{46}$ The weekly Port Unionbased The Fishermen's Advocate, once the official newspaper of the Fishermen's Protective Union, weighed in on 18 November about the “considerable comment" on "Holmes' Case." Despite being a strong critic of the undemocratic nature of the Commission, the newspaper cautioned that there were "so many sides to this question" and "so many facts connected with it which [have] not yet come out" that it was impossible for the newspaper to "hold, much less express, any fast or firm opinion." ${ }^{47}$

The Court decision also had had some potential implications for Britain's commercial relationship with the United States. Because Holmes's buyer in Puerto Rico was a business incorporated under American law, the Daily News asked the American assistant consul general at St. John's, Charles C. Sundell, what action had been taken by the consulate in connection with the non-shipment of Holmes's codfish, only to be told that the matter had been referred to the State 
Department in Washington. ${ }^{48}$ Consequently, Holmes informed the press that his principals in Puerto Rico were compelled to purchase their supplies of codfish from other producing countries. ${ }^{49}$ Sobrino appealed to the United States government, which instructed its consular general at St. John's to lodge a formal protest against the special legislation. ${ }^{50}$ Ewbank then met with Consul General Harold B. Quarton, ${ }^{51}$ who had been instructed by American Secretary of State Cordell Hall to raise two main issues with Ewbank, Quarton having been kept informed of the matter by Holmes. ${ }^{52}$ The first was to see if the agent for the Puerto Rican firm had exhausted his legal remedies and the second was to express his government's view that there were no justifiable grounds for the action of the Commission of Government in passing special legislation and refusing a special permit for the export of fish in fulfillment of a contract previously concluded in good faith. The US official also indicated that his government considered the action surprising, given that the United States was then concluding trade agreements with Canada and the United Kingdom that would provide real benefits to Newfoundland fishing interests and fishery exports to the United States. In response, Ewbank promised Quarton the "fullest possible statement of the facts of the case as known to us, and of the reasons which led to the action which we have taken," and a detailed summary followed. ${ }^{53}$ Fortunately, that trade agreement did not unravel as a result of this matter. It was signed in Washington on 17 November and provided for duties to be reduced on salt codfish from Newfoundland. Newfoundland's interests in the negotiations were overseen by Finance Commissioner J.H. Penson ${ }^{54}$ and by Gushue of the Fisheries Board..$^{55}$

The Newfoundland Board of Trade roundly criticized the Commission's action. The Board at this time was also unhappy with the Commission's policy in giving significant timber concessions in the Gander area to the new owners of the pulp and paper mill at Corner Brook, the English-owned Bowater-Lloyd Group. ${ }^{56}$ It subsequently passed a resolution declaring "its unqualified disapproval of the drastic action of the Newfoundland Commission of Government." ${ }^{57}$ The 
special Act was a "dangerous principle" adopted by a non-elected government whose "proceedings are conducted and whose legislative powers are exercised in private" and "tending to discredit the Rule of Law by which this country should be governed, to weaken Judicial authority in effectively upholding the civil rights of our people, and to awaken a feeling of insecurity in the public mind." In supporting the Commission's efforts in 1935 and 1936 to establish the Fisheries Board, the Board of Trade never envisaged the Fisheries Board would have so much "autocratic authority." It preferred the self-regulation of fish exports by trade committees and requested the immediate repeal of the 1938 special legislation. ${ }^{58}$

Ewbank responded to Board of Trade president Geoffrey Milling on 2 December. He claimed that the government had acted with "great reluctance" in enacting emergency legislation to prevent what the Supreme Court had regarded as the "lawful" completion of a commercial transaction. The Commission was worried that its action might be misinterpreted as "showing the lack of that regard for the authority of the Courts which it is the duty of the Commission of Government at all times to observe." The Commission had carefully considered an alternative but concluded that it had no time to pursue other options to the course adopted. The government had to act quickly to stop an "innocuous" transaction to prevent damaging a "scheme of orderly marketing of salt codfish, which had been laboriously and with great difficulty built up in consultation and co-operation with the Trade." Ewbank assured the Board president that the action taken on this occasion in "wholly exceptional circumstances" was not in any "sense a precedent to be followed in future." ${ }^{59}$ There was no intention to lessen the authority of the Fisheries Board unless the salt codfish export industry found itself in a position to "develop from within a cohesive organization whose authority in regard to price levels and control of marketing generally would be accepted by the fishermen and the export industry as a whole."The government preferred to leave the detailed working of marketing plans to the private sector and "confine themselves to general supervision and to assisting the organization 
by the exercise of their authority and powers." The government could not "accept responsibility" unless it also had "power." ${ }^{60}$

\section{Reaction in London}

Commissioners were also concerned about how their actions might be perceived in the British House of Commons. On 14 November Ewbank wrote P.A. Clutterbuck, an official in the Dominions Office who was regarded as the Newfoundland expert, sending background information on the Holmes "incident in connection with the fish market which may possibly form the subject of questions in the House [of Commons]." He acknowledged that the "action taken by us can be represented as an arbitrary interference by an irresponsible executive government with the rights of an individual as established in the High Court." Ewbank said they had been "in close touch with the Judges of the High Court and they have said candidly that they expected some action of the kind." On Sunday, 13 November, he had lunched with Justice Kent and "can say that there is no sense of resentment on their part at all at the action taken, no suggestion that the Executive Government are slighting the High Court and no friction between us." ${ }^{11}$

One champion of Newfoundland democratic rights in the House of Commons was British Tory MP Brendan Bracken, a journalist and newspaper publisher, ${ }^{62}$ who on 21 November questioned Malcolm MacDonald, the Secretary of State for the Dominions, ${ }^{63}$ on when Newfoundland could expect Dominion status to be restored. MacDonald informed Bracken that Newfoundland was not self-supporting and would not be "for a considerable time to come." The constitutional change in 1934 had taken place "at the request of the people of Newfoundland themselves." ${ }^{64}$ On 6 December Bracken again questioned MacDonald, asking would he issue immediate instructions to the Commission of Government to refrain from legislation that tended to "weaken the judiciary in upholding the civil rights of the people of Newfoundland." He then wrote MacDonald that the Holmes case was a "very grave development in affairs of the British Empire when a 
Dominion Government over-rules the judgment of a Supreme Court." MacDonald replied that the legislation had been passed in "very special circumstances" and that the "significance of it has been considerably exaggerated in such reports as he may have received," a view Bracken disputed. ${ }^{65}$ MacDonald explained to Bracken that the Commission had found it necessary to pass further legislation "remedying the defect in the Act which had been brought to light by the judgment of the Supreme Court." It was clear, he wrote Bracken, that from the Commission's public statement on the new legislation, there was no "desire on their part to interfere arbitrarily with the rights of an individual as established by the Court, and that their action resulted solely from the necessity for protecting the interests of the trade generally and ensuring to exporters an economic price for their fish." ${ }^{66}$

Bracken was having none of MacDonald's political response. "The affairs of the Fish Trade in Newfoundland may have given great concern to the Commission of Government," Bracken replied on 16 December, but, he added, if he were a Newfoundlander then he would have been much more "concerned by the Government's disregard for the Supreme Court." As Newfoundlanders no longer possessed the right of self-government, Bracken asserted that their only "protection against misrule is the right to appeal to the Courts. But if the decision of the judges can be immediately nullified by a private meeting of the Commissioners, citizens may rightly feel that the prosperity of the Fish Trade is less important than their limited civic rights." MacDonald continued to support the Commission; its decision, he reminded Bracken, should not be regarded in any "sense as a precedent for the future or as implying any lack of 'that regard for the authority of the Courts which it is the duty and the wish of the Commission of Government at all times to observe." Britain's desire to return democracy to Newfoundland was well understood by its people, and to make it self-supporting again, despite the poor international economic situation, "we can only do our best to carry it through these times of stress and to build up the earning power and the staying power of its small population." ${ }^{67}$ 
The Holmes case had caused "something of a stir in Newfoundland," Clutterbuck informed a senior official of the Foreign Office on 2 January 1939. The Foreign Office was "soon allayed by the public statements" made by the Commission, who acted quickly to explain its policy to the Newfoundland people. ${ }^{6}$ In a 31 December 1938 dispatch to Governor Walwyn, ${ }^{69}$ MacDonald notified him that the British government approved of the amending legislation, ${ }^{70}$ while Sir E.C. Machtig, ${ }^{71}$ assistant undersecretary at the Dominions Office, wrote Walwyn on 2 January 1939 that "it is hoped that we shall now hear no more of the matter" as the Commission did the "only thing possible in the circumstances." ${ }^{\prime 2}$ In late December Gushue initiated discussions with Holmes's lawyers to reach a settlement to the dispute. The government accepted the principle that a claim for expenses was incurred as a result of the legislation it had reluctantly adopted to protect Newfoundland's marketing policy in Puerto Rico. In turn, Holmes agreed to co-operate with the Puerto Rico Exporters Limited in future fish sales to Puerto Rico. ${ }^{73}$ The outbreak of war in Europe in 1939 and the Commission's mobilization of the Island's human and natural resources for the Allied war effort not only silenced the Commission's critics, but also fundamentally changed the economic and financial situation in Newfoundland through the establishment of several American and Canadian military bases that provided considerable employment and lessened the people's dependency on the salt-cod fishery.

\section{Conclusion}

The Holmes case highlighted the determination of the Commission of Government through the Fisheries Board to bring regulatory order to a marketing system in the salt codfish industry that had long been characterized by excessive competition and rivalry. But it also illustrates how that unelected government had overstepped its authority by impeding Holmes's rights and undermining the authority of the judicial system. Holmes had a voice in the courts by way of a mandamus as an avenue to bring his views and issues before the public. The 
Supreme Court granted him his remedy, but the Commission neutralized that by enacting retrospective legislation overruling the judicial system. The non-elective nature of the government allowed it to act swiftly, in the absence of debate in a legislature, to bring all aspects of the administrative and legal systems to bear to remedy a serious legal challenge to the regulatory authority of the Fisheries Board. However, the Commission was sensitive to public opinion and used the court case, both then and later, to explain better its general public policy. Meanwhile, the Fisheries Board emerged from the Holmes case of 1938 stronger and with more support from the business community. The Board strengthened its co-operative marketing organizations in other designated markets, which led in 1947 to it organizing all salt codfish exporters into one marketing organization, the Newfoundland Association of Fish Exporters Limited. ${ }^{74}$

\section{Acknowledgements}

The author would like to thank James Candow (Dartmouth), Augustus G. Lilly, Q.C. (St. John's), Dr. Raymond Blake (Regina), and Dr. Peter Neary (London, Ontario) for their comments on an earlier version of this paper.

\section{Notes}

1 On the establishment of the Commission in 1934 and subsequent public attitude towards it, see Peter Neary, Nerfoundland in the North Atlantic World, 1929-1949 (Montreal and Kingston: McGill-Queen's University Press, 1988); Susan McCorquodale, "Public Administration in Newfoundland during the Period of the Commission of Government: A Question of Political Development" (PhD thesis, Queen's University, 1973); James Overton, "Riots, Raids and Relief, Police, Prisons and Parsimony: The Political Economy of Public Order in Newfoundland in the 1930s," in Elliott Leyton, William O'Grady, and James Overton, eds., Violence and Anxiety (St. John's: ISER Books, 1992), 195-334; Declan Robert Cullen, "What To Do about Newfoundland?: 
Colonial Reconstruction and the Commission of Government, 19331941" (PhD thesis, Syracuse University, 2013), 227-82; Jeff A. Webb, "Newfoundland's National Convention, 1946-48" (MA thesis, Memorial University, 1987), 10-22; Raymond B. Blake and Melvin Baker, Where Once They Stood: Nerwfoundland's Rocky Road Towards Confederation (Regina: University of Regina Press, 2019), 182-95.

2 A writ of mandamus is a judicial remedy consisting of a court order to a government, a subordinate court, a public corporation, or statutory body to compel that public body to act under a statutory obligation. See https://en.oxforddictionaries.com/definition/mandamus and https://dictionary.law.com/Default.aspx?letter=M.

3 One exception is Patrick O'Flaherty, Leaving the Past Bebind: Newfoundland History from 1934 (St. John's: Long Beach Press, 2011), 41-42. He observed that the "speed with which the law was made brought home how complete the Commission's power was."

4 Peter Neary, ed., White Tie and Decorations: Sir John and Lady Hope Simpson in Newfoundland, 1934-1936 (Toronto: University of Toronto Press, 1996), 3-21.

5 Raymond Gushue (1900-1980). A graduate of the Dalhousie University Law School in 1925, he served as president of the Board of Trade in 1933 and 1934, having previously served on the Board's Fish Committee. In 1935 Gushue accepted an appointment as chair of the Salt Codfish Board and of the Newfoundland Fisheries Board in 1936, serving until 1952 when he became president of Memorial University.

6 Neary, ed., White Tie and Decorations, 16.

7 Robert Hong, “'An Agency for the Common Weal': The Newfoundland Board of Trade, 1909-1915" (MA thesis, Memorial University, 1998).

8 On efforts in 1919-21 to regulate the markets, see Edward Roberts, "Nothing Venture, Nothing Have: Mr. Coaker's Regulations" (MA thesis, Memorial University, 2006), 4-6, 59-68; Patrick O’Flaherty, Lost Country: The Rise and Fall of Nerwfoundland, 1843-1933 (St. John's: Long Beach Press, 2005), 299-303, 466; Ian D.H. McDonald, "To Each His Own": William Coaker and the Fishermen's Protective Union in Newfoundland Politics, 1908-1925 (St. John's: ISER Books, 1987), 86-105; Sean Cadigan, Death on Two Fronts: National Tragedies and the Fate of Democracy in Newfoundland, 1914-24 (Toronto: Penguin 
Canada, 2013), 210-29; Melvin Baker, “Challenging the 'Merchants' Domain': William Coaker and the Price of Fish, 1908-1919," Newfoundland and Labrador Studies 29, 2 (Fall 2014): 189-226.

9 Acts of the Honourable Commission of Government of Nerwfoundland, 1936, 1936 Newfoundland Fisheries Board Act, No. 11.

10 Ibid., 1936 Salt Codfish Association Act, No. 12.

11 Rooms Provincial Archives (RPA), Department of Natural Resources Papers, Departmental Files, GN31.2, Box 1, file 5, vol. 1, Gushue to Hope Simpson, 21 July 1936.

12 Maritime History Archive (MHA), Memorial University, Nafel Fonds, Collection \#1, Newfoundland Fisheries Board, Box 261, 1936-1941, file 6.06.001, Minute of the Newfoundland Fisheries Board, 24 Apr. 1936; RPA, Department of Justice Files, GN13/1/B, Box 136, file 35, Lewis Brookes to Secretary for Justice, 31 Jan. 1939.

13 Ray Gushue, "Newfoundland's Salt Codfish Industry Adopts the Pool Plan," Atlantic Guardian 4, 1 (Oct. 1947): 10-13.

14 David Alexander, The Decay of Trade: An Economic History of the Newfoundland Saltfish Trade, 1935-1965 (St. John's: ISER, 1977), 23; Neary, Newfoundland in the North Atlantic World, 153, 84-85.

15 John T.Cheeseman (1892-1968), member, Newfoundland Fisheries Board, 1936-42.

16 Claude Fraser (1905-1944), secretary, Department of Natural Resources, 1934-42.

17 RPA, Baine Johnston Papers, MG4, Box 12C, file "Correspondence - Puerto Rico Association, 1937” for a copy of the 20 Dec. 1937 Cheeseman report; MHA, Nafel Fonds, Box 261, file 6.06.003, Minute of the Newfoundland Fisheries Board, 15 Oct., 3 Dec. 1937; RPA, Department of Natural Resources Papers, Departmental Files - Administrative, GN31/3/C, Box 8, file "Porto Rico," George J. Tessier to John T. Cheeseman, Acting Chairman, Salt Codfish Exportation Board, 24 Mar. 1934. Newfoundland's share of total imports had risen from 40 per cent in 1930/31 to over 63 per cent in 1932/33.

18 Robert Benson Ewbank (1883-1967), Commissioner of Natural Resources, 1936-39, one of the three appointed British members of the Commission.

19 RPA, GN13/1/B, Box 326, file 48, Gushue memo to Ewbank, 3 Oct. 
1938; Box 136, file 35, Gushue to Ewbank, 9 Nov. 1938.

20 MHA, Nafel Fonds, Box 261, file 6.06.003, Minute of the Newfoundland Fisheries Board, 3 Nov. 1938, 1026; Daily News, 31 Oct. 1938. Fortune salt codfish exporter Harold Bertram Clyde Lake (18841964) was appointed acting manager.

21 Daily Nerws, 14 Nov. 1938; RPA, GN31.1, Box 6, NR 73-'38, Gushue memo dated 11 Nov. 1938.

22 Daily Nerws, 9 Nov. 1938; Observer's Weekly, 15 Nov. 1928; Fishermen's Advocate, 18 Nov. 1938.

23 Observer's Weekly, 7 Jan. 1952. Before enlisting, Holmes was a bank clerk. He later was attached to the Royal Flying Corps, qualifying as a pilot on 21 May 1918. On 18 November 1918 he was promoted to the rank of lieutenant, having risen through the ranks from his first promotion as lance corporal on 9 May 1916. On his service in the Great War, see his attestation papers at https://www.therooms.ca/holmes-arthur-chesley. Holmes became involved in the Newfoundland fish trade with his appointment in 1920 as a clerk in the St. John's office of London-based George Hawes, a broker and agent who had represented several major Newfoundland fish exporters in Spain and Italy since 1911. Holmes then transferred to Hawes's office in Alicante, Spain, and subsequently became involved in the fish importing business in Oporto, Portugal, until 1936, when he returned to Newfoundland. Holmes remained in the fishery export business until 1941 when he joined the Royal Canadian Air Force, rising to the rank of squadron leader. Following the war, he worked with Fishery Products Ltd of St. John's. In October 1951 the Newfoundland government appointed him to carry out a special survey of the traditional markets for Newfoundland salt codfish. His employment in this regard was brief, for on 3 January 1952 he died of heart failure in Paris. See RPA, Department of Fisheries, GN34/2, Box 11, file 9/44, "A Chesley Holmes," copy of Minute of Executive Council No. 967-'51; and Observer's Weekly, 7 Jan. 1952; Daily Nerws, 4 Jan. 1952; Evening Telegram 5 Jan. 1952.

24 Holmes letter dated 31 Dec. 1937 in the Daily News, 4 Jan. 1938.

25 RPA,GN31/3/C, Box 8, file "Porto Rico,"Tessier to Cheeseman, Acting Chairman, Salt Codfish Exportation Board, 24 Mar. 1934.

26 Edmund Joseph Phelan (1902-2005). 
27 Evening Telegram, 16, 17 Nov. 1938; Daily News, 17, 18 Nov. 1938.

28 William R. Howley (1875-1941), Commissioner for Justice and Attorney General 1934-38, Registrar of the Supreme Court, 1938-41.

29 James Mary Kent (1872-1939), Supreme Court Justice, 1916-39; William John Higgins (1880-1942), Minister of Justice and Attorney General 1924-28, Supreme Court Justice, 1928-43.

30 Daily News, 12, 14 Nov. 1938; Evening Telegram, 10 Nov. 1938.

31 RPA, GN13/1/B, Box 326, file 48, Gushue memo to Ewbank, 11 Nov. 1938.

32 Lewis Edward Emerson (1890-1949), Commissioner for Justice, 1937-44 and Chief Justice of the Supreme Court 1944-49.

33 RPA, Department of Natural Resources Papers, GN38, S2-2-1, file 7, NR 73-'38, Ewbank memo dated 12 Nov. 1938.

34 Holmes as interviewed in the Daily News, 14 Nov. 1938.

35 Evening Telegram, 15 Nov. 1938.

36 An Act to Prohibit the Export of Codfish Save under Permit for Export, (Signed and enacted by His Excellency the Governor on Saturday November 12th, 1938). See Acts of the Honourable Commission of Government of Nerwfoundland, 1938, No. 44; Evening Telegram, 14 Nov. 1938.

37 Daily News, 14 Nov. 1938.

38 See his letters in the Evening Telegram, 17 Nov. 1938; Daily News, 18 Nov. 1938.

39 RPA, Department of Natural Resources Papers, GN31.1, Memorandum, Box 6, NR 73(a)-’38, Gushue to Ewbank, 18 Nov. 1938.

40 Dominions Office Records, Newfoundland Correspondence, DO35/732, N69/10, Ewbank to Clutterbuck, 14 Nov. 1938, available at the Rooms Provincial Archives.

41 Daily News, 14 Nov. 1938.

42 Charles Ernest Augustine Jeffery (1881-1964), editor of the Evening Telegram, 1923-59.

43 Evening Telegram, 14 Nov. 1938.

44 Daily News, 15 Nov. 1938.

45 Albert Perlin (1901-1978). See Francis G. Hollohan, Albert Perlin: A Biography (St. John's: Jesperson Press, 1985).

46 Observer's Weekly, 22 Nov. 1938, 10 Jan. 1939. 
47 Fishermen's Advocate, 18 Nov. 1938. The Advocate was the official newspaper of the Fishermen's Protective Union since 1910, two years after the Union's founding. Policy differences had led the Union in January 1938 to distance itself from this paper and to establish a new newspaper, the Fishermen-Workers Tribune (there are no known copies extant of this paper for late 1938). See Fishermen's Advocate, $24 \mathrm{Dec}$. 1937, 14 Jan. 1938; Observer's Weekly, 11 Jan. 1938. On the Union, see McDonald, “To Each His Own”; Melvin Baker, "Coaker, Sir William Ford," Dictionary of Canadian Biography, http://www.biographi.ca/en/ bio/coaker_william_ford_16E.html.

48 Daily Nerws, 14 Nov. 1938.

49 Ibid., 18 Nov. 1938.

50 DO35/732, N69/12, Ewbank to Clutterbuck, 7 Dec. 1938.

51 Quarton was consular general at St. John's, 1934 to 1942. See Neary, Newfoundland in the North Atlantic World, 153, 174.

52 RPA, GN31.1, Box 6, NR 73(a)-'38, Gushue to Ewbank, 18 Nov. 1938.

53 Ibid., memo prepared by Ewbank for the Commission dated 18 Nov. 1938; NR 73 (b)-'38, Quarton to Ewbank, 18 Nov. 1938; DO35/732, N69/12, Ewbank to Quarton, 25 Nov. 1938.

54 John Hubert Penson (1893-1979), Commissioner for Finance, 1937-41.

55 Evening Telegram, 17, 18, 23, 26 Nov. 1938; Daily News, 19, 28 Nov., 16 Dec. 1938. The Fisheries Board was also actively investigating fisheries diversification through the development of a fresh fish industry with a prospective market in the United States. See Miriam Wright, A Fishery for Modern Times: The State and the Industrialization of the Newfoundland Fisheries, 1934-1968 (Toronto: Oxford University Press, 2001), 10-36.

56 Neary, Newfoundland in the North Atlantic World, 86; James K. Hiller, "The Politics of Newsprint: The Newfoundland Pulp and Paper Industry, 1915-1939," Acadiensis 19, 2 (Spring 1990), 33-37.

57 RPA, Board of Trade Papers, MG73, Box 34, file 8, Ewbank to Milling, 2 Dec. 1938; Fishermen's Advocate, 2 Dec. 1938; Observer's Weekly, 15, 29 Nov. 1938.

58 Evening Telegram, 25, 26 Nov. 1938; Observer's Weekly, 29 Nov. 1938; 
RPA, MG73, Box 34, file 8, for a copy of the resolutions.

59 RPA, MG 73, Box 34, file 8, Ewbank to Milling, 2 Dec. 1938.

60 Ibid.; Evening Telegram, 2 Dec. 1938.

61 DO35/732, dispatch N.69, Ewbank to Clutterbuck, 14 Nov. 1938.

62 Brendan Rendall Bracken, 1st Viscount Bracken (1901-1958),

Irish-born businessman and London publisher and journalist and

Conservative MP, 1929-51. See https://en.wikipedia.org/wiki/

Brendan_Bracken.

63 Malcolm MacDonald (1901-1981), British Secretary of State for Dominion Affairs, 1938-39.

64 Quoted in the Evening Telegram, 23 Nov. 1938.

65 RPA, GN38, S2-2-1, file 7, NR 73-'38, extract from the Official Report of 6 Dec. 1938, and MacDonald to Bracken, 12 Dec. 1938; Evening Telegram, 10 Dec. 1938.

66 RPA, GN38, S2-2-1, file 7, NR 73-'38, MacDonald to Bracken, 12 Dec. 1938 with attached note.

67 RPA, GN28, Box S-2-2-1, file 7 "Holmes Fish Shipments to Puerto Rico”; DO35/732, N69/15, Brendan Bracken to MacDonald, 16 Dec. 1938, and MacDonald to Bracken, 24 Dec. 1938.

68 Following the visit in early 1939 of the British reporter Morley Richards and the publication of a series of critical articles by him in the British newspaper the Daily Express, the Commission and Clutterbuck compiled an extensive response for the British government in case it had to defend the Commission publicly. See Peter Neary, "P.A. Clutterbuck on Morley Richards and the Record of the Commission of Government, 1939," Newfoundland and Labrador Studies 27, 1 (2012): 79-98; RPA, GN13/1/B, Box 297, file “Morley Richards' visit, Commentary on Daily Express articles on Newfoundland Affairs of March 27th to April 1st," dated 13 May by Robert Ewbank.

69 Sir Humphrey Walwyn (1879-1957), Governor of Newfoundland, 1936-46.

70 RPA, GN13/1/B, Box 371, file 44, MacDonald to Walwyn, 31 Dec. 1938.

71 Sir Eric G. Machtig (1889-1973).

72 DO35/732, N69/12, Clutterbuck to J.V. Perowne, 2 Jan. 1939, and to Ewbank, 2 Jan. 1939; RPA, GN38, S2-2-1, file 7, Machtig to Walwyn, 2 Jan. 1939. 
73 RPA, GN13/1/B, Box 326, file 48, Fox, Knight \& Phelan to Gushue, 30 Dec. 1938, Ewbank to Commissioners for Justice and for Finance and to Gushue, 4 Jan. 1939; Fishermen's Advocate, 13 Jan. 1939;

Observer's Weekly, 10 Jan. 1939.

74 See Alexander, The Decay of Trade, 19-100. The Daily Nerws on 31 Dec. 1948 described NAFEL as one of the "most important business operations in the country and the key to the economic structure" of Newfoundland. 